\title{
OPEN A parameter study of ultrasound assisted enzymatic esterification
}

\author{
Anamaria Vartolomei, Ioan Calinescu, Mircea Vinatoru \& Adina lonuta Gavrila \\ This work is focused on the study of the esterification parameters for the ultrasound assisted synthesis \\ of isoamyl acetate catalyzed by lipase Lipozyme 435 in a continuous loop reactor. Investigating the \\ influence of different parameters shows that a higher concentration of ester $(462 \mathrm{mg} / \mathrm{g} \mathrm{mixture})$ can \\ be obtained at a temperature of $50^{\circ} \mathrm{C}$, flow rate $0.16 \mathrm{~mL} / \mathrm{min}$. The best ultrasonication conditions are: \\ sonication applied continuously for a short time $(20 \mathrm{~min})$, ultrasound power $32 \mathrm{~mW}$ and amplitude \\ $20 \%$. The enzyme can be successfully reused tree times without loss of enzyme activity. Reaction \\ kinetics for isoamyl acetate ultrasound assisted production showed that satisfactory reaction \\ concentration (close to the equilibrium concentrations) could be reached in short reaction times ( $2 \mathrm{~h}$ ). \\ Ultrasound assisted enzymatic esterification is consequently a cleaner and a faster process.
}

Biocatalysts, green, clean and efficient products, are increasingly used to replace chemical catalysts, especially due to their high specificity, regio- and stereo- selectivity in mild conditions, leading to a sustainable chemical process ${ }^{1}$. Enzymes, protein with catalytic activity, have been used in processes producing: biofuel ${ }^{2}$, food and beverage $^{3}$, in research and biotechnologies ${ }^{4,5}$, in cleaning products ${ }^{6}$, for diagnostics ${ }^{7}$, animal feed ${ }^{8}$. Enzyme immobilization on a suitable support is a need to increase its reusability. In general, such a process (immobilization) reduces the efficiency of enzymes ${ }^{9}$ caused by the immobilization procedures and by mass-transfer limitations ${ }^{10}$. The uses of immobilized enzymes is still challenging due to their costs and storage problems ${ }^{11}$. However, due to the easiness of products recovery, purification and separation, immobilized enzymes are preferred over free enzymes ${ }^{12}$. For this reason, methods to maintain or activate the immobilized enzymes are of paramount importance.

There are several methods to overcome the current limitations related to immobilized enzymes, some of them being chemically binding ${ }^{13}$, the use of sub- and supercritical carbon dioxide for the enhancement of enzymatic activity and stability (case of $\alpha$-amylase), multiple-site mutagenesis of lipase B Candida Antarctica ${ }^{14,15}$. Among these methods, ultrasound as a meaning to enhance the activity of enzymes is a very promising technique. Improving the activity of tyrosinase ${ }^{16}$, enzymatic hydrolysis of starch for better glucoamylase activity ${ }^{17}$, and dual frequency ultrasound enhancing enzymolysis of potato protein ${ }^{18}$ are among several known examples. Cebrián-García et al. ${ }^{19}$ studied the ultrasound-assisted esterification of valeric acid to alkyl valerates promoted by biosilicified lipases. Biosilicified enzymes had slightly improved specific activities and product yields for the ultrasound-assisted esterification compared to the free enzyme in ethanol.

Using acoustic waves on enzymes causes increase in the mass transfer rate of the reagents to the active site ${ }^{20}$. Acoustic cavitation influence protein conformation, unfolding the polypeptide chain and reveling the active site $^{21}$. Consequently, ultrasound can assist the enzymes contact with substrates ${ }^{16}$. In the reaction mixture, the shear forces caused by mechanical effects of ultrasound intensify the mass transfer, leading to the decrease of diffusion barrier ${ }^{22}$. Several research studies prove that ultrasound affects differently distinct enzymes, each having a specific tolerance and sensitivity to ultrasound. In order to reach the maximum value of catalytic activity the optimum ultrasonic conditions must be determined, known being that high power ultrasound ends up in enzymes denaturation ${ }^{23,24}$. Often, a low intensity, short duration ultrasonic treatment is more likely to enhance enzyme activity, while prolonged exposure may lead to loss of stability and decrease in enzyme activity ${ }^{20,25}$.

In our previous paper ${ }^{26}$ the bio-catalyzed ultrasound assisted synthesis of isoamyl acetate was reported, and another feature of ultrasound, namely unlocking the Lipozyme 435 enzyme for a specific enzymatic esterification was described.

The main objective of this paper is to develop new data regarding the biocatalytic effect of Lipozyme 435 under ultrasound-assisted esterification of acetic acid with isoamyl alcohol. The novelty of this paper is the intensification of the enzymatic esterification process using a continuous loop reactor. The thermodynamics involved in the enzymatic esterification was also evaluated following the influence of process conditions on the reaction rate, monitoring some of the reaction's parameters such as temperature and residence time. With these new data in 
hands, the best sonication conditions (ultrasonic power and duty cycle) and the reusability of enzymes, for this particular enzymatic process were established.

\section{Materials and methods}

Materials. Acetic acid (analytical grade, 99.99\% purity) was purchased from Chemical Company CHIMOPAR SRL, Romania. Isoamyl alcohol $(\geq 98 \%)$ was provided by Sigma-Aldrich. The commercial enzyme used as catalyst was Lipozyme 435 provided by curtesy of Novozyme, Denmark, as a Candida antarctica lipase immobilized on a macroporous anion exchange resin. The enzyme support, Duolite A 568 (Duolite International SA, Paris), is a porous granular, weak base anion exchange resin based on a cross-linked phenol-formaldehyde polycondensate with a hydrophilic structure and controlled pore size distribution. Acetone was purchased from Chemical Company Chimreactiv SRL, Romania.

Experimental setup. The esterification reaction was carried out in a loop reactor ${ }^{26,27}$ described in our $^{2}$ previous work. The advantage of using a loop reactor is to minimize cavitation activity and maximize mass transfer ${ }^{26}$. The esterification reactions carried out at $50{ }^{\circ} \mathrm{C}$ with various flow rates and an acid-to-alcohol molar ratio of 1:2. The total volume of esterification mixture was $5 \mathrm{~mL}$ and it was maintained constant for all reactions. Sonication was performed using a probe system (Vibracell VCX-750), with a power supply setting at various amplitude (20-30\%). The samples were taken at certain reaction times and analyzed by gas chromatography. All the experiments were carried in triplicates to check the reproducibility of the results and certainly the obtained data were reproducible and the experimental errors were less than $\pm 3 \%$ of the reported average values of the results. Results from tables snd figures are expressed as mean \pm standard deviation of the values obtained in triplicates.

Gas chromatography analysis (GC). Quantitative analysis of the esters was performed using an HP 6890 gas chromatograph equipped with flame ionization detector (FID). The column used was a HP-INNOWAX $19091 \mathrm{~N}-133$ cross-linked PEG with $30 \mathrm{~m} \times 250 \mu \mathrm{m}$. The oven was set to heat the column from 50 to $250^{\circ} \mathrm{C}$ under a heating gradient of $10^{\circ} \mathrm{C} / \mathrm{min}$. Helium was the carrier gas (flow rate $1 \mathrm{~mL} / \mathrm{min}$ ) and $n$-butanol was used as an internal standard for the ester concentration. The samples were analyzed in duplicates.

Kinetics of esterification process. The reaction between acetic acid and isoamyl alcohol is an equilibrium-limited reversible reaction:<smiles>CC(=O)O</smiles>

A<smiles>[O-][C+][I-]</smiles>

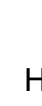<smiles>O</smiles><smiles>CCCCCCCO</smiles>

B<smiles>CC(=O)OCCC(C)C</smiles>

An isoamyl alcohol excess was used to drive the reaction toward the product's side. The activation energy for the conventional reaction and the ultrasound assisted reaction were calculated. In order to assess the activation energy, the rate constant was determined from the general reaction rate equation:

$$
-r_{A}=\frac{\partial C_{A}}{\partial t}=\frac{\partial C_{B}}{\partial t}=k C_{A} C_{B} \gamma_{A} \gamma_{B}
$$

where: $\gamma_{A}$ and $\gamma_{B}$ are activity coefficients, $C_{A}$ and $C_{B}$ are concentrations of the reagents during the reaction and $\mathrm{k}$ is rate constant.

It is assumed that the concentration of reagents depends on the initial concentrations $\left(\mathrm{C}_{\mathrm{A} 0}\right.$ and $\left.\mathrm{C}_{\mathrm{B} 0}\right)$ and each component fraction $\left(\mathrm{X}_{\mathrm{A}}\right.$ and $\left.\mathrm{X}_{\mathrm{B}}\right)$ and the reaction rate can be rewritten as follow:

$$
-r_{A}=C_{A 0} \frac{\partial X_{A}}{\partial t}=k\left(C_{A 0}-C_{A 0} X_{A}\right)\left(C_{B 0}-C_{A 0} X_{A}\right) \gamma_{A} \gamma_{B}
$$

The initial molar ratio is $M=\frac{C_{B 0}}{C_{A 0}}$. For an ideal system, $\gamma_{\mathrm{A}}$ and $\gamma_{\mathrm{B}}$ are considered constants, so the logarithm of Eq. (2) can be rearranged to yield the reaction rate constant in Eq. $(3)^{28}$.

$$
n \frac{1-X_{B}}{1-X_{A}}=\ln \frac{M-X_{A}}{M\left(1-X_{A}\right)}=\ln \frac{C_{B} C_{A 0}}{C_{B 0} C_{A}}=\ln \frac{C_{B}}{M C_{A}}=(M-1) C_{A 0} k t
$$

Several experiments have been carried out to analyze the influence of temperature, for both conventional heating and ultrasound assisted reactions. The temperature dependency of esterification reaction was determined by calculating the activation energy $\left(E_{a}\right)$ at different temperature levels. For this, the Arrhenius Law was used:

$$
k=A e^{\frac{-E a}{R T}}
$$

where: $E_{a}$ is the activation energy, $\mathrm{A}$ is pre-exponential factor, $\mathrm{R}$ is the universal gas constant $(8.314 \mathrm{~J} / \mathrm{mol} \mathrm{K})$, and $\mathrm{T}$ is the absolute temperature. 


\begin{tabular}{|l|l|l|l|l|}
\hline \multirow{2}{*}{ Ultrasonic amplitude, \% } & \multicolumn{2}{|l|}{ Ultrasonic power, W } & \multicolumn{2}{l|}{ Ultrasonic power density, W/mL } \\
\cline { 2 - 5 } & In reactor & In coupling fluid & In reactor & In coupling fluid \\
\hline 20 & $0.032 \pm 0.002$ & $12 \pm 1.0$ & $0.053 \pm 0.0003$ & $0.103 \pm 0.008$ \\
\hline 25 & $0.044 \pm 0.004$ & $17 \pm 1.8$ & $0.073 \pm 0.0006$ & $0.144 \pm 0.015$ \\
\hline 30 & $0.068 \pm 0.0045$ & $27 \pm 1.6$ & $0.114 \pm 0.00075$ & $0.227 \pm 0.013$ \\
\hline
\end{tabular}

Table 1. Ultrasonic power absorbed in the reactor and in the coupling fluid and ultrasonic power density.

The equilibrium concentration of the ester was determined considering a value of 4.9 for the equilibrium constant ${ }^{29}$. The equilibrium concentration of ester $\left(\mathrm{C}_{\text {eq }}\right)$ for our reaction is $477 \mathrm{mg} / \mathrm{g}_{\text {mixture }}$, and the maximum ester concentration $\left(\mathrm{c}_{\max }\right)$ for isoamyl acetate is $551 \mathrm{mg} / \mathrm{g}_{\text {mixture }}$ (for a molar ratio alcohol:acid = 2:1).

Enzyme reusability. Enzyme reuse requires a washing step before the next esterification reaction. For this, at the end of each enzymatic esterification, the immobilized lipase was washed with acetone for $10 \mathrm{~min}$, at room temperature. After removing the solvent, the lipase was dried in an air current flow (previously passed through an active charcoal filter) at $50^{\circ} \mathrm{C}$ for $15 \mathrm{~min}$ and reused in a new reaction.

Determination of ultrasonic power by calorimetric method. Several methods are available to estimate the amount of ultrasound power that has entered a sonochemical reaction ${ }^{30,31}$. Calorimetry is the most used method, and it involves measuring the initial rise of temperature produced when a system is irradiated by acoustic power. This assumes that almost all mechanical energy produces heat and thus the output power can be obtained by calorimetry. The temperature rise of a fixed amount of reaction mixture, in an isolated glass reactor and in the coupling fluid, at a given time, was measured. Using this information, the energy dissipated in the liquid, inside the reactor, and in the coupling fluid, was calculated (Table 1) using Eqs. (5) and (6).

$$
\begin{gathered}
Q=m \times c_{p} \times \Delta T \\
P=\frac{Q}{t}
\end{gathered}
$$

where $\mathrm{Q}$ is the quantity of heat (joule), $\Delta \mathrm{T}$ is the temperature variation $\left({ }^{\circ} \mathrm{C}\right), \mathrm{m}$ is the mass of fluid $(\mathrm{kg})$ and $\mathrm{c}_{\mathrm{p}}$ $\left(\mathrm{kg} /{ }^{\circ} \mathrm{C}\right)$ is the specific heat, $\mathrm{P}$ is the ultrasonic power $(\mathrm{W})$ and $\mathrm{t}$ (seconds) is the time in which the temperature rise was measured.

It is observed that as the amplitude of the applied ultrasound increases, the difference between the power absorbed in the reactor and the power absorbed in the coupling fluid is increasing.

\section{Results and discussion}

The influence of ultrasonic power. To study the effect of the ultrasound power, experiments were performed by varying the amplitude from 20 to $35 \%$ to find the best power needed in order to achieve an efficient cavitation generation to perform esterification without damaging the enzyme. With the increase of amplitude, the energy input in the reaction system increases, too, leading to a higher number of cavitation bubbles and therefore to more chances to damage the enzyme. The amplitudes over $40 \%$ physically damage the enzymes. The amplitude together with the duty cycle and sonication time are parameters showing how the ultrasonic power could influences the enzyme and enzymatic activity. Ultrasounds can increase enzymatic catalytic rate by two phenomena, either by increasing mass transfer or by directly influencing the enzyme ${ }^{32}$. Both effects were followed in the experimental program. At the beginning, the power of the continuously applied ultrasound was changed by rising the amplitude from 20 to $30 \%$. As shown in Fig. 1, ultrasound causes a significant increase in the reaction rate in the first $20 \mathrm{~min}$, but later it is found that at high powers (44-68 $\mathrm{mW}$ ) an inhibition of enzyme activity occurs and consequently the reaction rates decrease. Thus, the $20 \%$ amplitude was considered optimal and it was used for the following studies.

The influence of duty cycle. The power is a very important parameter for the ultrasonic assisted reactions. For classical esterification reactions, higher ultrasound power gives higher conversions ${ }^{33}$. In case of enzyme catalyzed reaction, ultrasounds may lead to improvement in enzyme activity ${ }^{34}$. High ultrasonic powers may deactivate, or even denature the enzyme ${ }^{35}$. A series of experiments were performed to identify the optimum required ultrasound power for enzyme activation. In order to modify the ultrasonic power, instead of continuously sonication, the acoustic duty cycle was used and the results are shown in Figs. 2 and 3. However, the use of the duty cycle did not lead to better results than the continuous use of ultrasound with an amplitude of $20 \%$ regardless of the flow rate used.

These experimental data showed that the use of pulse ultrasound mode ( $3 \mathrm{~s}$ on $/ 3 \mathrm{~s}$ off $)$ gives almost similar results as for continuous sonication using less grid power (half), as seen in Table 2. Even if the ester concentration is higher for continuous sonication, the difference is low, only $4.4 \%$, this could be considered an advantage of pulse sonication. 

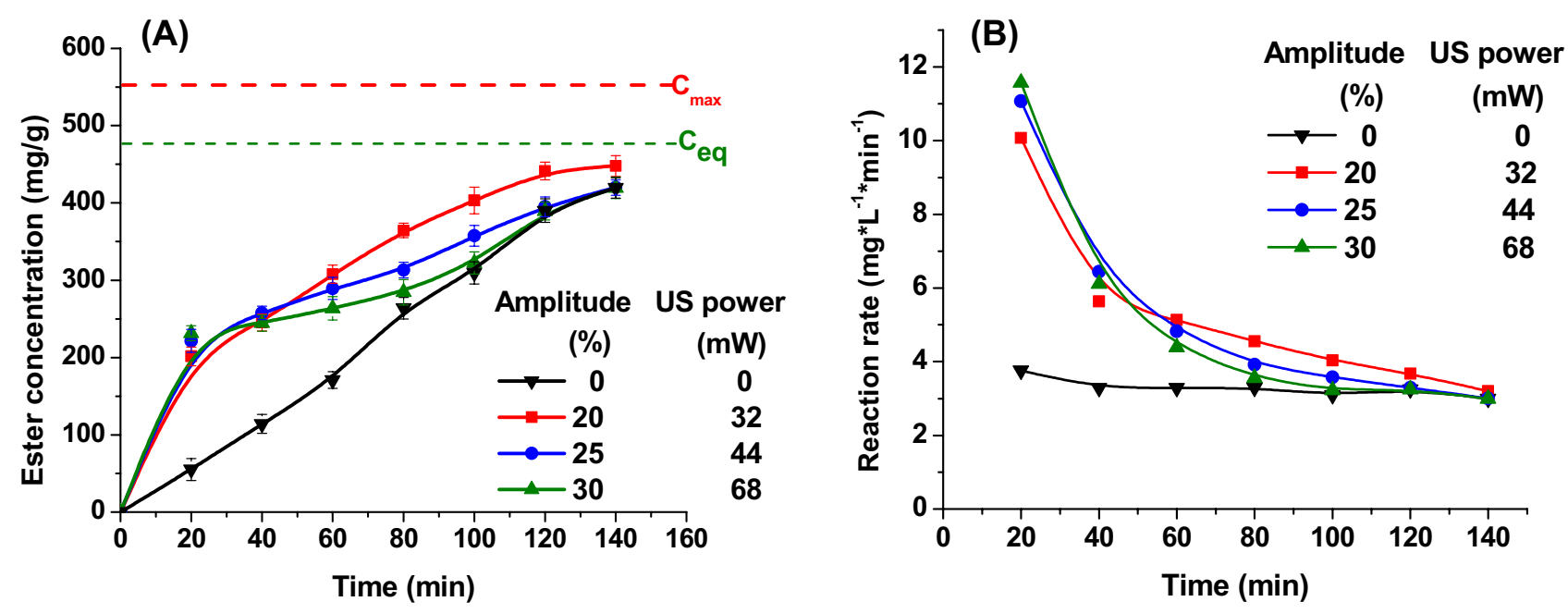

Figure 1. The influence of ultrasound amplitude on the ester concentration (A) and on the reaction rate (B) (reaction conditions: temperature $50^{\circ} \mathrm{C}$, flow rate $0.16 \mathrm{~mL} / \mathrm{min}$ ).

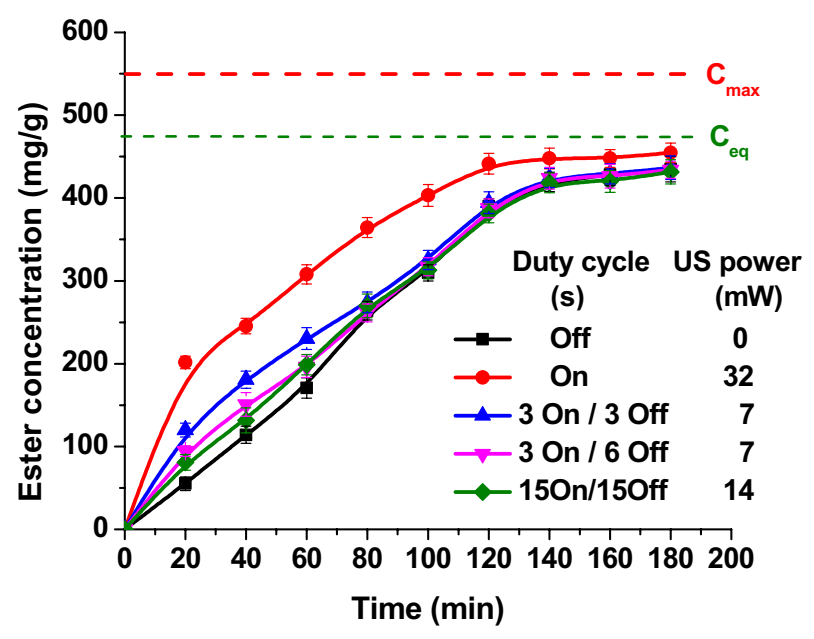

Figure 2. The influence of the sonication power on the ester concentration (reaction conditions: temperature $50{ }^{\circ} \mathrm{C}$, flow rate $0.16 \mathrm{~mL} / \mathrm{min}$, ultrasonication time $3 \mathrm{~h}$, ultrasound amplitude $20 \%$ ).

The influence of the sonication time. In literature, it is reported that long-time exposure to ultrasound at low temperature leads to the enzyme inactivation by splitting of low molecular weight polypeptides or individual amino acids and the oxidative mechanisms ${ }^{36}$. Ultrasonic shear stresses generated by acoustic cavitation can degrade polymers of high molecular mass and promotes enzyme denaturation ${ }^{37}$. Wang et al. ${ }^{38}$, studied the effects of low intensity ultrasound on cellulase pretreatment, noticing that the highest activity of immobilized cellulase was reached when the sample was treated with ultrasounds, $24 \mathrm{kHz}$ and $60 \mathrm{~W}$ US power, for $10 \mathrm{~min}$. Using scanning electron microscopy (SEM) they proved that the ultrasonic treatment lead to an increase in the surface area of the immobilized cellulase. When the enzyme was treated with ultrasounds for a short period of time activity of the enzyme was increased by $24.67 \%$ over the control.

To establish optimal sonication time for Lipozyme 435 experiments at different continuous ultrasound exposures: 10, 20, 40 and 60 min were performed, as shown in Fig. 3. It can be noticed that the best results were obtained when ultrasounds were applied for $20 \mathrm{~min}$, the ester concentration increased with $27.4 \%$. The possible reason for this could be that applying ultrasound for $20 \mathrm{~min}$ provides enough energy for the activation of enzyme, and better exposure of enzymatic active sites, without denaturing Lipozyme 435 enzyme. 10 min ultrasonic treatment is not enough for the enzyme activation, and 40 and $60 \mathrm{~min}$ are too much, the ultrasound starting to affect physically Lipozyme 435 enzyme.

Activation energy measurements. To determine the apparent activation energy for conventional and for ultrasonically assisted process, a series of enzymatic esterification reactions has been performed at different reaction temperatures: 30,40 and $50{ }^{\circ} \mathrm{C}$. As shown in Fig. 4 , it is obvious that ester concentration increases with 


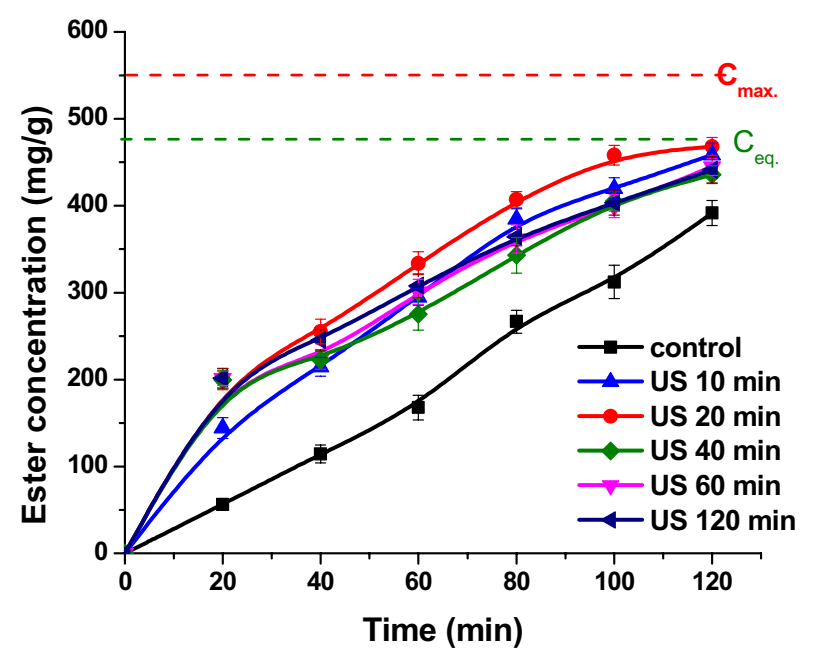

Figure 3. The influence of the sonication time on the ester concentration (reaction conditions: temperature $50{ }^{\circ} \mathrm{C}$, acid to alcohol molar ratio $1: 2$, flow rate $0.16 \mathrm{~mL} / \mathrm{min}$, continuous ultrasonication, power $20 \mathrm{~W}$, amplitude $20 \%)$.

\begin{tabular}{|l|l|l|l|}
\hline Amplitude, \% & $\begin{array}{l}\text { Grid } \\
\text { power, } W\end{array}$ & $\begin{array}{l}\text { Power absorbed in the reactor } \\
\text { (determined by calorimetry), W }\end{array}$ & $\begin{array}{l}\text { Power read } \\
\text { from Vibracell, } \\
\text { W }\end{array}$ \\
\hline off & 22 & 0 & 0 \\
\hline 20 & 60 & 0.032 & 20 \\
\hline 25 & 73 & 0.044 & 30 \\
\hline 30 & 86 & 0.068 & 43 \\
\hline $20 \%(3$ s on $/ 3$ s off $)$ & 30 & 0.016 & 10 \\
\hline
\end{tabular}

Table 2. Different powers applied to the system.

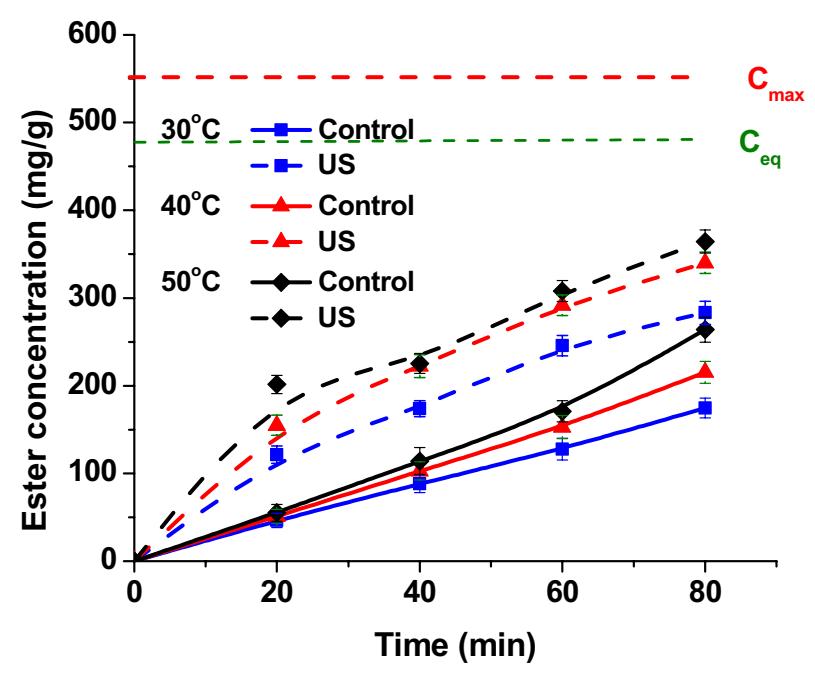

Figure 4. The influence of temperature on the ester concentration for control and ultrasound assisted esterification (reaction conditions: flow rate $0.16 \mathrm{~mL} / \mathrm{min}$, continuous ultrasonication, power $20 \mathrm{~W}$, amplitude $20 \%)$.

increasing temperature. The effect of ultrasound is obvious, ester concentrations are significantly higher in the case of ultrasound-assisted reactions.

The activation energy for each esterification reaction can be determined by plotting the logarithm from rate constant versus the reciprocal of absolute temperature as shown in Fig. 5. The calculated activation energies for both reactions are presented in Table 3. 


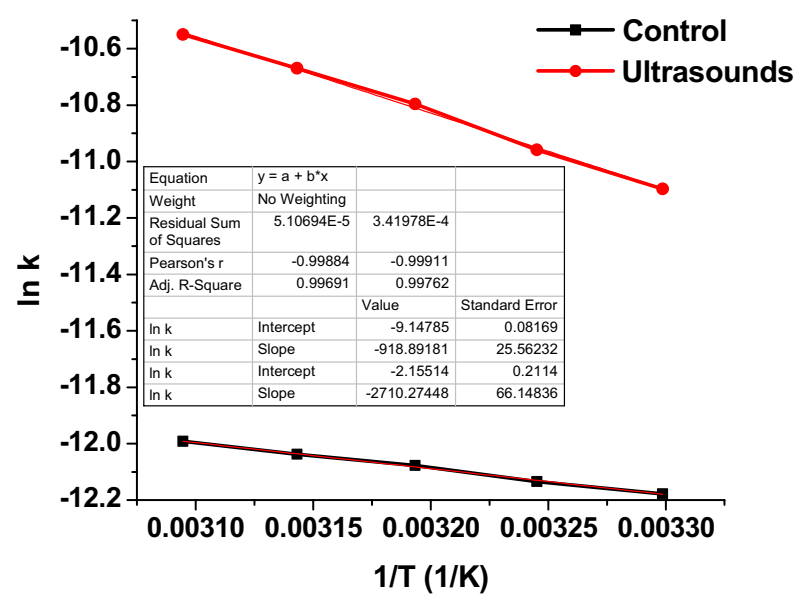

Figure 5. Arrhenius plot of effective reaction rates for control and ultrasound assisted esterification (reaction conditions: temperature $50{ }^{\circ} \mathrm{C}$, flow rate $0.16 \mathrm{~mL} / \mathrm{min}$, continuous ultrasonication, power $20 \mathrm{~W}$, amplitude $20 \%$ ).

\begin{tabular}{|l|c|c|}
\hline Reaction conditions & Slope, $\mathbf{K}$ & $\mathbf{E}_{\mathbf{a}}, \mathbf{J} / \mathbf{m o l}$ \\
\hline Control & -918.892 & 7640.1 \\
\hline Ultrasound & -2710.27 & $22,534.6$ \\
\hline
\end{tabular}

Table 3. The activation energy for control and ultrasound assisted enzymatic esterification calculated using Arrhenius diagram.

The apparent activation energy $\left(\mathrm{E}_{\mathrm{a}}\right)$ for the synthesis of isoamyl acetate in the presence of ion-exchange resins determined in literature was in the range $42-45 \mathrm{~kJ} / \mathrm{mol}^{39,40}$. Enzymes are biocatalysts that lower the activation energy $\left(E_{a}\right)$ that is required to convert the substrates to products ${ }^{41}$. However, immobilizing the enzyme, diffusion may become rate limiting and the reaction may switch from kinetic to diffusion controlled resulting in a change in the measured apparent $\mathrm{E}_{\mathrm{a}}$.

From the analysis of the data presented in Table 3 it can be noticed that the apparent activation energies in the absence of ultrasound is very low, which means that the process takes place in diffusion mode. When ultrasound is applied, the apparent activation energy increases greatly, indicating the shift to the kinetic regime. This value is consistent with those determined for esterification reactions in the presence of enzymes immobilized in organogel agar. The diffusion study has revealed that the structure of these organogels does not provide a barrier for the substrates to enter the catalyst ${ }^{41}$.

The influence of flow rate. The flow rate is important for the process of continuous esterification reactions. Lower values of residence time determine higher productivity. For this study three different reactants flow rates: $0.16,0.3$ and $0.7 \mathrm{~mL} / \mathrm{min}$ where used. The results are presented in Fig. 6.

For conventionally carried out reactions the flow rate is very important. Lower flow rates $(0.16 \mathrm{~mL} / \mathrm{min})$ assure longer contact time $(3.7 \mathrm{~min}$ ) between the reactants involved and the enzyme, resulting in a more efficient conversion.

Ultrasound assisted reactions lead to a higher isoamyl acetate concentration, for all three flow rates. The most important effect of ultrasound is observed when the flow rate is lower, in these conditions the combined effect of longer residence time and that of ultrasound determines the decrease of the diffusion resistance even more and consequently the increase of the conversion. But, the difference between the ester concentrations obtained by ultrasound assisted esterification at all flow rates is not higher. This behavior can be explained by mass transfer considerations. At higher flow rates, the mass transfer residences in the liquid phase is reduced by the turbulences generated by the bubbles inside the reactor. At higher flow rates, the regents mixing is more vigorous and intense, resulting in a more efficient conversion.

The enzyme reusability. One of the most important advantages when using immobilized enzymes is the prospect of their reusability, a crucial economic and environmental aspect for employing enzymes in industrial applications. The reusability and recovery of an enzyme is of high priority in order to decide if the bioprocess is viable or not. In order to evaluate the potential of immobilized lipase for industrial enzymatic esterification application, the stability of Lipozyme 435 was deduced by measuring the concentration of isoamyl acetate from successive esterification reaction under optimal conditions. The immobilized enzyme used, Lipozyme 435, after 


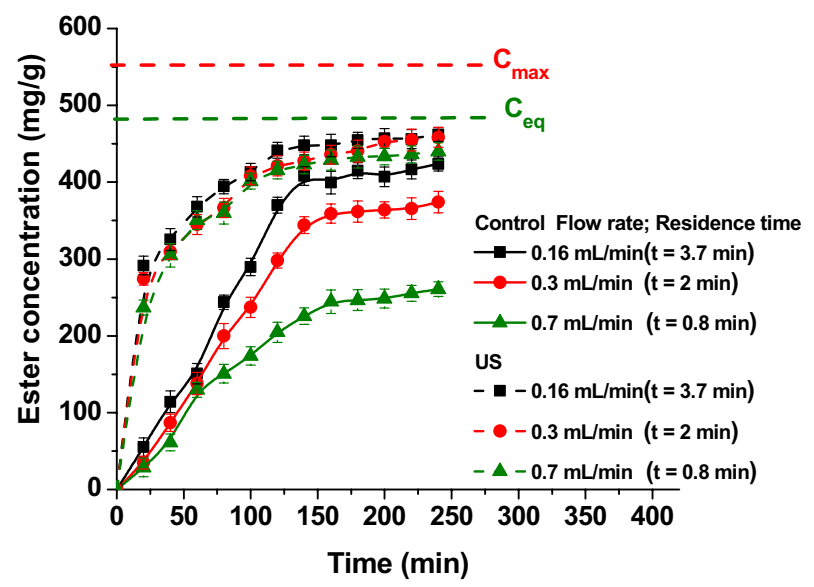

Figure 6. The influence of flow rate on ester concentration, by conventional and ultrasound assisted processes (reaction conditions: temperature $50{ }^{\circ} \mathrm{C}$, continuous ultrasonication, power $20 \mathrm{~W}$, amplitude $20 \%$ ).
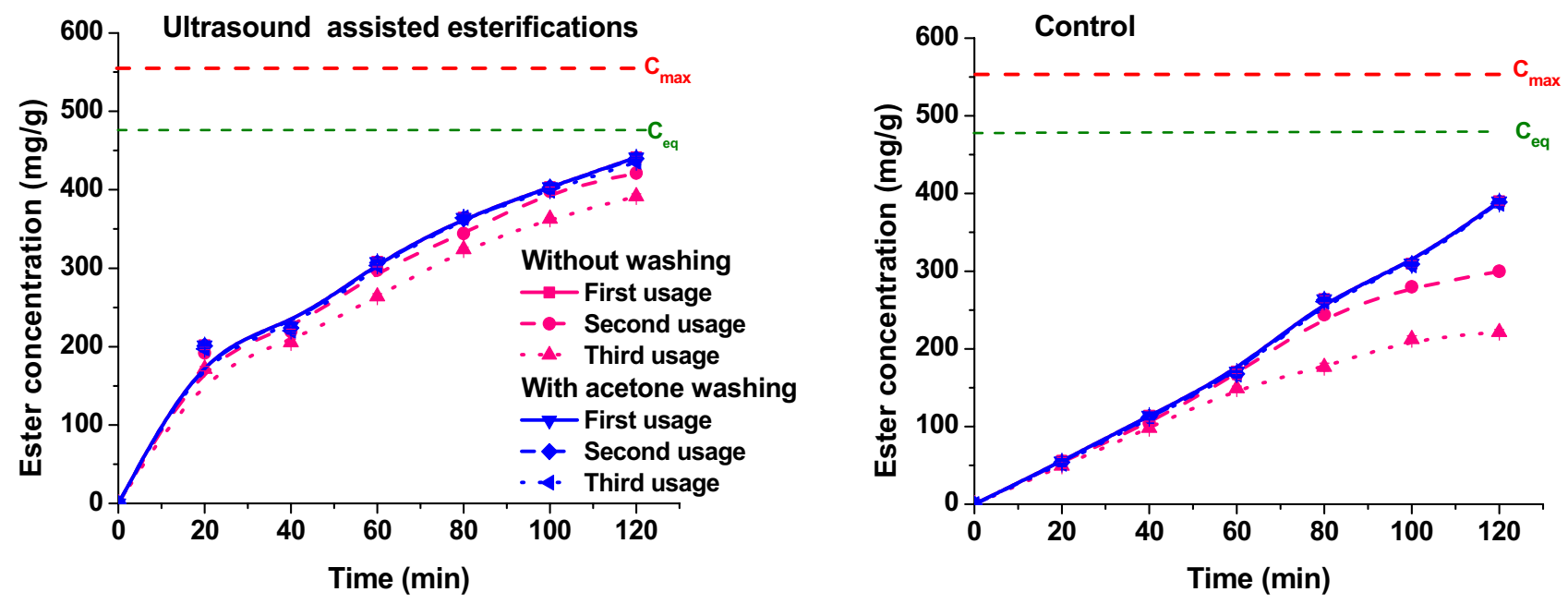

Figure 7. The influence of washing with acetone on the reusability of immobilized Lipozyme 435 for repeated cycles. by conventional process (reaction conditions: temperature $50{ }^{\circ} \mathrm{C}$ ) and ultrasound assisted process (continuous ultrasonication, power $20 \mathrm{~W}$, amplitude 20\%).

the enzyme was further washed with acetone and dried in a warm air flow and reused. Washing with acetone is a crucial step to remove accumulation of product and acid content from the environment of the immobilized biocatalyst. The residue of acid and isoamyl ester may block active sites of lipase and hinder the next successive reaction cycles yielding lower ester concentrations ${ }^{42}$.

The use of Lipozyme 435 enzyme in three consecutive reactions, without acetone washing after each reaction results in an isoamyl concentration decrease. This decrease in the enzyme activity was noticed in both reactions with conventional heating and ultrasound assisted reactions, as presented in Fig. 7. The possible reason for this could be the blockage of Lipozyme 435 active sites due to the retention of some reactants or/and product (especially acetic acid) or the breakdown of Lipozyme 435 beads during the reaction, as a consequence of mechanical effects of ultrasound ${ }^{43}$.

The isoamyl acetate concentration in conventional heating reaction with acetone washing, after three consecutive uses, lowers with $1 \%$, comparative with the reactions without acetone washing, were the isoamyl ester concentration drops with $43.33 \%$. For the ultrasound assisted reaction, the ester concentration drop without washing was of $11.33 \%$. Washing with acetone after each reaction, the ester concentration drop after three consecutive reactions was only $1.36 \%$.

Thus, these results clearly show significant improvement in Lipozyme 435 reusability and regeneration when using the acetone washing method. 


\section{Conclusion}

The esterification process of acetic acid with isoamyl alcohol catalyzed by the commercial enzyme Lipozyme 435 was carried out. The best sonication conditions to improve Lipozyme 435 activity, stability and reusability were determined. The results indicate that the maximum ester concentration was obtained for ultrasound-assisted process at temperature $50{ }^{\circ} \mathrm{C}$, flow rate $0.16 \mathrm{~mL} / \mathrm{min}$. The best ultrasonication conditions are: continuously applied sonication for a short time $(20 \mathrm{~min})$, ultrasound power $32 \mathrm{~mW}$, and amplitude $20 \%$. The results show a favorable perspective to improve the esterification efficiency and reduce the reaction time, using ultrasounds for short time periods. The calculated activation energy for the synthesis of isoamyl acetate is $7640.1 \mathrm{~J} / \mathrm{mol}$ for conventional esterification and $22,534.6 \mathrm{~J} / \mathrm{mol}$ for ultrasound-assisted reaction. In this enzymatic esterification, the enzyme can be reused several times after regeneration by washing with acetone, making the process cost effective. The results achieved in this research can be used for scaling up the process at higher level.

Received: 4 October 2021; Accepted: 13 January 2022

Published online: 26 January 2022

\section{References}

1. Wong, C.-H., Whitesides, G. M. \& Baldwin, J. E. Tetrahedron organic chemistry series. Volume 12, enzymes in synthetic organic chemistry. J. Chem. Educ. 72, A94. https://doi.org/10.1021/ed072pA94.10 (1995).

2. Binod, P., Gnansounou, E., Sindhu, R. \& Pandey, A. Enzymes for second generation biofuels: Recent developments and future perspectives. Bioresour. Technol. Rep. 5, 317-325. https://doi.org/10.1016/j.biteb.2018.06.005 (2019).

3. Zhang, Y., He, S. \& Simpson, B. K. Enzymes in food bioprocessing-novel food enzymes, applications, and related techniques. Curr. Opin. Food Sci. 19, 30-35. https://doi.org/10.1016/j.cofs.2017.12.007 (2018).

4. Asgher, M., Shahid, M., Kamal, S. \& Iqbal, H. M. N. Recent trends and valorization of immobilization strategies and ligninolytic enzymes by industrial biotechnology. J. Mol. Catal. B Enzym. 101, 56-66. https://doi.org/10.1016/j.molcatb.2013.12.016 (2014).

5. Kirk, O., Borchert, T. V. \& Fuglsang, C. C. Industrial enzyme applications. Curr. Opin. Biotechnol. 13, 345-351. https://doi.org/10. 1016/s0958-1669(02)00328-2 (2002).

6. Sharma, B., Dangi, A. K. \& Shukla, P. Contemporary enzyme based technologies for bioremediation: A review. J. Environ. Manag. 210, 10-22. https://doi.org/10.1016/j.jenvman.2017.12.075 (2018)

7. Basso, A. \& Serban, S. Industrial applications of immobilized enzymes-A review. Mol. Catal. 479, 110607. https://doi.org/10. 1016/j.mcat.2019.110607 (2019).

8. Jegannathan, K. R. \& Nielsen, P. H. Environmental assessment of enzyme use in industrial production-A literature review. J. Clean. Prod. 42, 228-240. https://doi.org/10.1016/j.jclepro.2012.11.005 (2013).

9. Bernal, C., Rodriguez, K. \& Martinez, R. Integrating enzyme immobilization and protein engineering: An alternative path for the development of novel and improved industrial biocatalysts. Biotechnol. Adv. 36, 1470-1480. https://doi.org/10.1016/j.biotechadv. 2018.06.002 (2018).

10. Datta, S., Christena, L. R. \& Rajaram, Y. R. Enzyme immobilization: An overview on techniques and support materials. 3 Biotech. 3, 1-9. https://doi.org/10.1007/s13205-012-0071-7 (2013)

11. Wahab, R. A., Elias, N., Abdullah, F. \& Ghoshal, S. K. On the taught new tricks of enzymes immobilization: An all-inclusive overview. React. Funct. Polym. 152, 104613. https://doi.org/10.1016/j.reactfunctpolym.2020.104613 (2020).

12. Cebrián-García, S., Balu, A. M., García, A. \& Luque, R. Sol-gel immobilisation of lipases: Towards active and stable biocatalysts for the esterification of valeric acid. Molecules 23, 2283. https://doi.org/10.3390/molecules2309228313 (2018).

13. Tong, Y., Xin, Y., Yang, H., Zhang, L. \& Wang, W. Efficient improvement on stability of sarcosine oxidase via poly-lysine modification on enzyme surface. Int. J. Biol. Macromol. 67, 140-146. https://doi.org/10.1016/j.ijbiomac.2014.03.015 (2014).

14. Senyay-Oncel, D. \& Yesil-Celiktas, O. Activity and stability enhancement of alpha-amylase treated with sub- and supercritical carbon dioxide. J. Biosci. Bioeng. 112, 435-440. https://doi.org/10.1016/j.jbiosc.2011.07.012 (2011).

15. Yagonia, C. F. J., Park, H. J., Hong, S. Y. \& Yoo, Y. J. Simultaneous improvements in the activity and stability of Candida antarctica lipase B through multiple-site mutagenesis. Biotechnol. Bioprocess Eng. 20, 218-224 (2015).

16. Yu, Z. L., Zeng, W. C. \& Lu, X. L. Influence of ultrasound to the activity of tyrosinase. Ultrason. Sonochem 20, 805-809. https:// doi.org/10.1016/j.ultsonch.2012.11.006 (2013).

17. Wang, D. et al. Ultrasound assisted enzymatic hydrolysis of starch catalyzed by glucoamylase: Investigation on starch properties and degradation kinetics. Carbohydr. Polym. 175, 47-54. https://doi.org/10.1016/j.carbpol.2017.06.093 (2017).

18. Cheng, Y. et al. Improving the enzymolysis efficiency of potato protein by simultaneous dual-frequency energy-gathered ultrasound pretreatment: Thermodynamics and kinetics. Ultrason. Sonochem. 37, 351-359. https://doi.org/10.1016/j.ultsonch.2017.01.034 (2017).

19. Cebrián-García, S., Balu, A. M. \& Luque, R. Ultrasound-assisted esterification of valeric acid to alkyl valerates promoted by biosilicified lipases. Front. Chem. 6, 197. https://doi.org/10.3389/fchem.2018.00197 (2018).

20. Delgado-Povedano, M. M. \& Luque de Castro, M. D. A review on enzyme and ultrasound: A controversial but fruitful relationship. Anal. Chim. Acta 889, 1-21. https://doi.org/10.1016/j.aca.2015.05.004 (2015).

21. Subhedar, P. B. \& Gogate, P. R. Enhancing the activity of cellulase enzyme using ultrasonic irradiations. J. Mol. Catal. B Enzym. 101, 108-114. https://doi.org/10.1016/j.molcatb.2014.01.002 (2014).

22. Mason, T. J. Advances in Sonochemistry Vol. 5 (Jai Press INC, 1999).

23. Özbek, B. \& Ülgen, K. Ö. The stability of enzymes after sonication. Process Biochem. 35, 1037-1043. https://doi.org/10.1016/S00329592(00)00141-2 (2000).

24. Ma, X. et al. Properties and structures of commercial polygalacturonase with ultrasound treatment: Role of ultrasound in enzyme activation. RSC Adv. 5, 107591-107600 (2015).

25. Fazlena, H., Norsuraya, S. \& Nadiah, S. N. In 2013 IEEE Business Engineering and Industrial Applications Colloquium (BEIAC) 85-90.

26. Calinescu, I., Vartolomei, A., Gavrila, I. A., Vinatoru, M. \& Mason, T. J. A reactor designed for the ultrasonic stimulation of enzymatic esterification. Ultrason. Sonochem. 54, 32-38. https://doi.org/10.1016/j.ultsonch.2019.02.018 (2019).

27. Vinatoru, M. \& Mason, T. Comments on the use of loop reactors in sonochemical processes. Ultrason. Sonochem. 39, $240-242$. https://doi.org/10.1016/j.ultsonch.2017.04.033 (2017).

28. Levenspiel, O. Chemical Reaction Engineering (Wiley, 1999).

29. Duque-Bernal, M. et al. Kinetic study on the homogeneous esterification of acetic acid with isoamyl alcohol. Int. J. Chem. Kinet. 45, 10-18. https://doi.org/10.1002/kin.20737 (2013).

30. Kimura, T. Standardization of ultrasonic power for sonochemical reaction. Ultrason. Sonochem. 3, S157-S161. https://doi.org/10. 1016/s1350-4177(96)00021-1 (1996).

31. Berlan, J. \& Mason, T. J. Advances in Sonochemistry Vol. 4, 73 (JAI Press Inc., 1996).

32. Vulfson, E. N., Sarney, D. B. \& Law, B. A. Enhancement of subtilisin-catalysed interesterification in organic solvents by ultrasound irradiation. Enzyme Microb. Technol. 13, 123-126. https://doi.org/10.1016/0141-0229(91)90166-8 (1991). 
33. Grönroos, A., Aittokallio, N. \& Kolehmainen, E. Ultrasound accelerated esterification of bile acids. Ultrason. Sonochem. 11, 161-165. https://doi.org/10.1016/j.ultsonch.2004.01.013 (2004).

34. Avhad, D. N. \& Rathod, V. K. Ultrasound stimulated production of a fibrinolytic enzyme. Ultrason. Sonochem. 21, 182-188. https:// doi.org/10.1016/j.ultsonch.2013.05.013 (2014).

35. Martins, A. B. et al. Ultrasound-assisted butyl acetate synthesis catalyzed by Novozym 435: Enhanced activity and operational stability. Ultrason. Sonochem. 20, 1155-1160. https://doi.org/10.1016/j.ultsonch.2013.01.018 (2013).

36. Thakur, B. R. \& Nelson, P. E. Inactivation of lipoxygenase in whole soy flour suspension by ultrasonic cavitation. Food Nahrung 41, 299-301. https://doi.org/10.1002/food.19970410510 (1997).

37. Tian, Z. M., Wan, M. X., Wang, S. P. \& Kang, J. Q. Effects of ultrasound and additives on the function and structure of trypsin. Ultrason. Sonochem. 11, 399-404. https://doi.org/10.1016/j.ultsonch.2003.09.004 (2004).

38. Wang, Z. et al. Effects of low intensity ultrasound on cellulase pretreatment. Bioresour. Technol. 117, 222-227. https://doi.org/10. 1016/j.biortech.2012.04.015 (2012).

39. Lee, M.-J., Wu, H.-T., Kang, C.-H. \& Lin, H.-M. Kinetics of catalytic esterification of acetic acid with amyl alcohol over amberlyst 15. J. Chem. Eng. Jpn. 34, 960-963. https://doi.org/10.1252/jcej.34.960 (2001).

40. Teo, H. \& Saha, B. Heterogeneous catalysed esterification of acetic acid with isoamyl alcohol: Kinetic studies. J. Catal. 228, 174-182. https://doi.org/10.1016/j.jcat.2004.08.018 (2004).

41. Zoumpanioti, M. et al. Esterification reactions catalyzed by lipases immobilized in organogels: Effect of temperature and substrate diffusion. Biotech. Lett. 30, 1627-1631. https://doi.org/10.1007/s10529-008-9734-1 (2008).

42. Martins, A. B. et al. Rapid and high yields of synthesis of butyl acetate catalyzed by Novozym 435: Reaction optimization by response surface methodology. Process Biochem. 46, 2311-2316. https://doi.org/10.1016/j.procbio.2011.09.011 (2011).

43. Bansode, S. R. \& Rathod, V. K. Ultrasound assisted lipase catalysed synthesis of isoamyl butyrate. Process Biochem. 49, $1297-1303$. https://doi.org/10.1016/j.procbio.2014.04.018 (2014).

\section{Acknowledgements}

The authors acknowledge the financial support received from the Competitiveness Operational Programme 20142020, Action 1.1.4: Attracting high-level personnel from abroad in order to enhance the RD capacity, project: P_37_471, „Ultrasonic/Microwave Nonconventional Techniques as new tools for nonchemical and chemical processes", financed by contract: 47/05.09.2016. The article processing charges were supported by University POLITEHNICA of Bucharest.

\section{Author contributions}

A.V. and A.I.G. performed the enzymatic esterifications, investigation, writing original draft; I.C. methodology, writing-review and editing; M.V. provided supervision for experimental work and manuscript preparation.

\section{Competing interests}

The authors declare no competing interests.

\section{Additional information}

Correspondence and requests for materials should be addressed to A.I.G.

Reprints and permissions information is available at www.nature.com/reprints.

Publisher's note Springer Nature remains neutral with regard to jurisdictional claims in published maps and institutional affiliations.

(c) (i) Open Access This article is licensed under a Creative Commons Attribution 4.0 International License, which permits use, sharing, adaptation, distribution and reproduction in any medium or format, as long as you give appropriate credit to the original author(s) and the source, provide a link to the Creative Commons licence, and indicate if changes were made. The images or other third party material in this article are included in the article's Creative Commons licence, unless indicated otherwise in a credit line to the material. If material is not included in the article's Creative Commons licence and your intended use is not permitted by statutory regulation or exceeds the permitted use, you will need to obtain permission directly from the copyright holder. To view a copy of this licence, visit http://creativecommons.org/licenses/by/4.0/.

(C) The Author(s) 2022 